\title{
Birger Poppel: A Pioneer in Greenlandic and Arctic Quality of Life Research
}

\section{Birger Poppel}

Received: 1 December 2013 / Accepted: 11 December 2013 / Published online: 10 January 2014 (C) Springer Science+Business Media Dordrecht and The International Society for Quality-of-Life Studies (ISQOLS) 2014

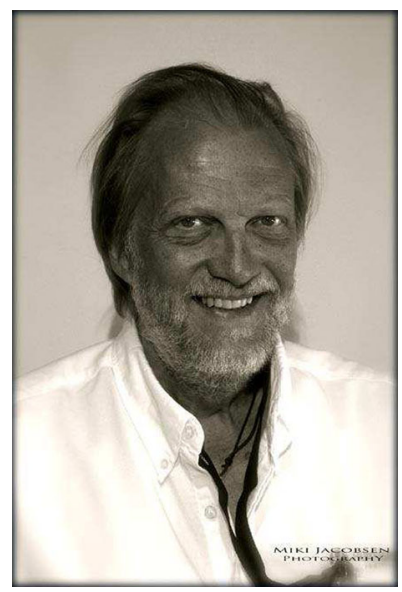

Birger Poppel was born in 1950 in Frederiksberg, Denmark and grew up there and in Copenhagen. His father was a master plumber and his mother was a full-time housewife. He completed his primary school education and received his General Certificate of Education in Copenhagen. With no family tradition for university education it was not in the cards that living conditions and quality of life studies should be part of his professional career. Based on his own youthful dreams his father urged him to study engineering but a profound interest in politics and societal development, including the unequal distribution of income and wealth, made him study 'Economics' at the University of Copenhagen. He was engaged in the student movement and gathered work experience from a variety of social science relevant positions, including with the Danish National Centre for Social Research and as an instructor at the University of Copenhagen. He received an MA in Economics in 1978.

B. Poppel $(\bowtie)$

Ilisimatusarfik, University of Greenland, Nuuk, Greenland

e-mail: bipo@uni.gl 
Poppel did not take the straight line from university to quality of life studies, though. His first job was as a civil servant with the municipality of Copenhagen (1978-1980) followed by four years as a consultant in the Danish Union of Social Welfare Workers. In 1984 he moved to - and eventually settled - in Greenland as he was offered a job as a consultant for a joint SIK (Greenland National Workers' Union)-Home Rule Government working group on a national unemployment insurance arrangement (2004-07).

Following jobs as a civil servant in the Greenland Home Rule administration he was offered a position as the first Chief Statistician of Statistics Greenland. He served as Chief Statistician from 1989 until 2004. Since 2004 he has served as Project Chief of the Survey of Living Conditions in the Arctic, SLiCA at Ilisimatusarfik, University of Greenland.

The primary task as Chief Statistician was to establish an independent and professional Greenland based statistical organisation. As Chief Statistician he was responsible for the first Living Conditions Survey in Greenland (1994) since the introduction of Greenland's Home Rule in 1979. The representative study that was asked for by the Greenland Parliament focused on conventional social indicators but failed to answer a number of questions about relationships and of well-being and quality of life. Together with Thomas Andersen (then senior consultant at Statistics Greenland) he prepared a follow-up study 10 years after. The ambition of this study was to include Inuit, Sami and other Arctic indigenous peoples, their knowledge, values and welfare priorities to jointly develop context specific living conditions dimensions and indicators through a bottom-up process in a close partnership between SLiCA's indigenous partners at local, regional and international levels (Inuit Circumpolar Council, ICC; Sami Council and Russian Association of Indigenous Peoples of the North, RAIPON) and a diverse group of social scientists (Andersen and Poppel, 2002).

To make SLiCA inclusive he and his colleagues initiated further collaborative initiatives with research communities, indigenous and other experts (including ISQOLS-colleagues and Statistics Canada), the Arctic Council (AC) and other stakeholders. The Arctic Council endorsed SLiCA as a Sustainable Development initiative in 2000. In 2010 the Senior Arctic Officials of the AC agreed that: 'The project is a major Arctic Council achievement providing a solid socio-economic knowledge basis about the living conditions in the Arctic and an excellent foundation for policy making.' (sao_report_torshavn_Oct_2010.pdf).

Following contacts at the Girona ISQOLS conference (1999) he hosted a conference in Nuuk, Greenland (2001) including internationally leading well-being and quality of life researchers and the SLiCA research team.

In 2007 he published results from the Inuit settlement regions together with Jack Kruse (who conducted a living conditions study among Inupiat in Northern Alaska in 1977), Gerard Duhaime and Larissa Abruitina (Poppel et al., 2007). Results and analyses have been published internationally in Springer volumes and other academic journals, in newspapers and journals for a larger audience (see e.g. Kruse et al., 2008 and Glatzer 2013). He has been a member of the Editorial Board of Social Indicator Research (SIR) since 2004 and field editor of the Encyclopaedia for Quality of Life Research (Alex Michalos, chief editor).

With the increased interest in mineral development in Greenland and consequently a demand for impact assessments he has delivered regional analyses based on SLiCA data and findings. 
Since the affiliation with Ilisimatusarfik, University of Greenland, in 2004, his main task has been the development of SLiCA focussing on living conditions, well-being and quality of life. Parallel to working with SLiCA he has been engaged in a number of other Arctic research projects as steering group member and lead/co-lead author: Economies of the North (ECONOR); Arctic Social Indicators (ASI); Political Economy of Northern Regional Development (POENOR); Snow, Water, Ice, Permafrost in the Arctic (SWIPA); and, Arctic Human Development Report (AHDR). The contributions to these research projects are based on his Arctic living conditions and quality of life research and include other research interests: the mixed market and harvest-herding based Arctic economies; the demographic, economic, social, cultural and political development in the Arctic region-including impacts of climate change and resource exploitation.

Beyond his research activities he has been a member of: the Commission for Scientific Research in Greenland (1994-2004), the Greenland Health Research Board (1997-2004) and the Greenland Home Rule Government Research Fund 2002-2009. From 2008 to 2012 he was an elected member of the board of governors of Ilisimatusarfik, University of Greenland. From 2005 to 2009 he served as the chairman of the National Greenland International Polar Year (IPY) Committee and as a board member of the Danish IPY Committee. He has served as a member of the council of International Arctic Social Sciences Association (IASSA) since 2001: from 2004 to 08 vice-president and convener of ICASS VI, International Congress of Arctic Social Sciences in 2008 .

\section{Selected References}

Andersen, T., \& Poppel, B. Living Conditions in the Arctic. (2002). In: Hagerty, M.R., Vogel, J. \& Møller, V. (eds.): Assessing Quality of Life and Living Conditions to Guide National Policy. The State of the Art. Social Indicators Research Series, Vol. 11. Kluwer Academic Publishers. Reprinted from: Social Indicator Research, Vol. 58, pp. 191-216, 2002.

Kruse, J., Poppel, B., Abryutina, L., Duhaime, G., Martin, S., Poppel, M., Kruse, M., Ward, E., Cochran, P., \& Hanna, V. (2008). Survey of Living Conditions in the Arctic, SLiCA. In: Møller, V., Huschka, D, \& Michalos, A. C. (eds.): Barometers of Quality of Life around the Globe. Springer Social Indicators Research Series. Springer Verlag, pp. 107-134.

Poppel, B., Kruse, J., Duhaime, \& G., Abryutina, L. (2007). Survey of living conditions in the arctic: SLiCA results. Anchorage: Institute of Social and Economic Research, University of Alaska Anchorage. http://www. arcticlivingconditions.org/. 666 pages.

Poppel, B . (2008). Measuring ways of living and living conditions of indigenous peoples of the arctic-The greenlandic inuit as an example. In: Engell, M. \& Søndergaard, J. (eds.): Menneskesjiel. Festskrift til Finn Lynge. Forlaget Atuagkat, pp. 97-117.

Poppel, B. \& Kruse, J. (2009). The importance of a mixed cash-and harvest herding based economy to living in the Arctic-an analysis based on Survey of Living Conditions in the Arctic (SLiCA). In: Møller, V. \& Huscka, D. (editors): Quality of Life in the New Millenium: Advances in Quality-of-Life Studies, Theory and Research. Social Indicators Research Series. Springer Verlag, pp. 107-134.

Poppel, B. (2013). Inuit Nunaat-The Inuit World: Measuring living conditions \& individual well-beingmonitoring human development using the Survey of Living Conditions in the Arctic (SLiCA) to augment ASI for the Inuit World. In: Larsen, J. N., Schweitzer, P., Petrov, A., \& Fondahl, G. (eds.) Arctic Social Indicators II. Nordic Council of Ministers. Copenhagen.

Poppel, B. (2013). Living Conditions, Subjective Well-being, Quality of Life among Indigenous Peoples in the Arctic. In: Glatzer, W.: Global Handbook of Subjective Well-being and Quality of Life. Springer Verlag. 